\title{
Libya's IAS/IFRS Adoption and Accounting Quality: What Lessons from the European Union Experience
}

\author{
Najeb Masoud \\ Accounting and Finance Department, Middle East University Business School, Jordan \\ PO box 383 Amman 11831, Jordan \\ Email: najeb2000@gmail.com
}

Accepted: January 29, 2014

DOI: 10.5296/ijafr.v4i1.5477 URL: http://dx.doi.org/10.5296/ ijafr.v4i1.5477

\begin{abstract}
This study provides a review of the literature on adoption of IAS/IFRS in Libya, the time the IFRS standards decision is made in EU countries and the time IAS/IFRS adoption becomes undertaking in Libyan economy. The adoption of IAS/IFRS in Europe on the quality of financial reporting is an example of accounting standardisation among countries with different institutional frameworks and implementation rules. Impacts of this adoption in Libya will gain many benefit include the improve quality of financial reporting, less earnings management, more comparability, and provide more reliable, accurate, transparency, and high relevance for stock price determination of financial accounting information. These findings could be fruitful and helpful for outside users of accounting reports and also for regulators and legislators in their attempts to constrain the incidence of earnings accounting practises and to enhance the quality of accounting information. To explore the relevance (applicability) of international accounting standards to developing countries such as Libya is a topic of significant interest amongst disclosure (non-accounting information) users. This is a key subject for standard setting purposes as IAS/IFRS have been adopted in many different nations all over the world, and many others are likely to adopt them in the near future (including, Libya). Finally the main limitations of this study are outlined and opportunities for future research are discussed, particularly in relation to this study's findings about the requirement to reconsider the usefulness of the relationship between accounting practices and framework adoption of IAS/IFRS in Libya.
\end{abstract}

Keywords: IAS/IFRS adoption, Accounting Quality, advantage, accounting standards, Libya, European Union Experience.

JEL Classifications: E50, H83, G10, G14, G15, K22, M41, M48 


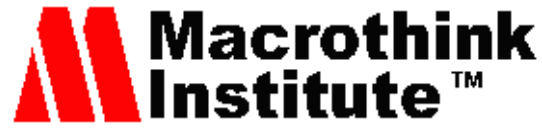

International Journal of Accounting and Financial Reporting

ISSN 2162-3082

2014, Vol. 4, No. 1

\section{Introduction}

The IAS/IFRS (International Accounting Standards/International Financial Reporting Standards) consist of a set of international accounting principles (IAP). Most of the nations' economies are developing; new accounting standards are needed to achieve the gap of needs which are produced by the new industries and transactions. IFRS was set to fill this gap and enhance the financial statements quality and coordination. IFRS which was issued by two boards International Accounting Standards Board (IASB) and Financial Accounting Standards Board (FASB) in London is gaining an increasingly a significant attention around the world as global standards for the financial statements. EU Regulation 1606/2002 has mandated the adoption of IAS/IFRS in all the member states of the EU with required the listed companies in the European stock market to apply IFRS on their financial statements. The implementation of IFRSs of which aims at establishing clear rules within the EU to drawn from a key transparent annual reports and financial statements. The financial statements have produced many effects on the firms adopting these standards. This in order to address in more detail the increasing interest to show which is the effect of the adoption of IAS/IFRS in accounting practice of European experience, and to demonstrate which are the consequences on their reported performance, as well as to provide evidence of the quantitative effect of the principal impacts emerging from the application of IAS/IFRS applied to Libyan accounting practice.

Our focus is on the implementation of IAS/IFRS from the EU experience, a key feature of the new adopt applicable model, which will be a fundamental change in Libya's accounting practices. We select Libya as our fundamental study setting due to the $2^{\text {nd }}$ largest oil producer in Africa and the continent's $4^{\text {th }}$ largest natural gas supplier, accounting for $38 \%$ for the continent's total, and the $9^{\text {th }}$ largest amount in the global economy. More significantly, Libya mostly exports to European markets since its economy has opened door policy, a development that will drive Libya's the adoption of IAS/IFRS on the quality of financial reporting further towards a western model, typified by the EU experiences. Libya could learn from EU experiences to adopt IAS/IFRS accounting report systems. This has meant that to a large extent, accounting principles, auditing standards, accounting fair value, accounting education, international accounting standards and the international financial reporting standards have been adopted from outside Libya and some of them applied without a thorough consideration of local environmental factors. This practice is problematic, since it is widely acknowledged that in developing or emerging economies, it is not possible, or even advisable, to impose western accounting systems without an understanding of the unique culture, political, economic, social and religious dynamics of those economies imperialism. There is very limited published research on accounting or the Libyan financial accounting reporting in particular (Bait-El-Mal et al., 1973; El-Sharif, 1980; Bait-El-Mal 1990; Bakar and Russell, 2003; Derwish and Elghli, 2006).The site of this study on existing research on the effects of the adoption of IAS/IFRS on the quality of financial reporting in all the member states of the European Union with the ultimate goal of increasing transparency in financial reporting on centrally planned or formerly centrally planned economies rather than primarily former European colonies. 


\section{MInstitute Macrothink $_{\text {Int }}$}

International Journal of Accounting and Financial Reporting

ISSN 2162-3082

2014, Vol. 4, No. 1

Libya's as an emerging economy, cultural, political and economic system is dramatically different from that of the EU countries, as developed countries. A primary contribution of this study is to addresses that gap, to adopt applicable model from the EU implantation of IAS/IFRS in Libya prior to its becoming an emerging economy, and makes possible the identification of specific challenges the practice of the Libyan high-quality reporting environment, in which financial accounting plays a more powerful contracting role than information role, and those in which the institutional environment is incompatible with IAS/IFRS in the future if it is to assist Libya in reaching its economic goals. There is no previous ground for literature on IAS/IFRS adoption and its impacts in Libyan economy, this study contributes to the based on a literature review and on original archival research from other countries especially US, UK, and European countries is reviewed. Finally, conclusions are drawn and recommendation made.

\section{Purpose of the Study}

The main purpose of this study is to identify, consider, evaluate, and comment on existing research on the effects of the adopting of applicable model from IAS/IFRS UE experiences to apply into the Libyan accounting practices. IAS/IFRS adoption should be improved to get the objects of fair value accounting with the crucial goal of increasing transparency and quality of financial reporting. IAS/IFRS adopted in the EU for twofold main reasons. On the one hand, IAS/IFRS adoption in the EU has been mandatory. On the other hand, it has involved different countries with different accounting standards. In order to establish global accounting standards, the International Accounting Standards (IAS) refers to standards issued by the International Accounting Standards Committee (IASC). In March 2000, a new IASC constitution was approved and the name of the international standard setting body was changed to the IASB. The new board (IASB) reports to IASC foundation and assumed its duties in April 2001. In this way, the International Financial Reporting Standards (IFRSs) which are issued by the (1ASB), the successor body to the (lASC). Starting from January 1, 2005, the European Community Regulation 1606/2002 required companies listed in regulated European markets to adopt the IAS/IFRS in all the member of the EU with the ultimate goal of increasing transparency and quality of financial reporting standards (see Figure 1).

The IASB's published standards which are issued by the IASB, that consistent in numerous countries all around the world, which is recognised as "best practice". For instance, the listed companies of 27 member states of the EU countries prepare their financial statements in conformity with IFRSs, instead of local followed a variety of country-specific Generally Accepted Accounting Principles (GAAP) ${ }^{\mathbf{1}}$. In 2007, the SEC in the United States of America announced that IAS/IFRS would be permitted in foreign companies listed on US markets as an alternative to US GAAP. Furthermore, the US Securities and Exchange Commission

\footnotetext{
${ }^{1}$ The 27 member states are: Austria, Belgium, Bulgaria, Cyprus, Czech Republic, Denmark, Estonia, Finland, France, Germany, Greece, Hungary, Ireland, Italy, Latvia, Lithuania, Luxembourg, Malta, Netherlands, Poland, Portugal, Romania, Slovakia, Slovenia, Spain, Sweden, and United Kingdom. Three additional European countries (Iceland, Liechtenstein, and Norway), while not EU member states, have agreed to abide by EU laws and regulations (http://www.ifrs.org/Use-around-the-world/Documents/Jurisdiction-profiles/European-Union-IFRS-Profile.pdf).
} 


\section{MInstitute ${ }^{\text {Mink }}$}

International Journal of Accounting and Financial Reporting ISSN 2162-3082

(SEC), has been taken major steps permitting the use of IFRS in the US (Barth et al., 2008; Hail et al., 2010). Various countries in parts of the Middle East and Africa, Asia, including Australia and US integrate their local GAAP to IFRSs (Mirza et al., 2006; Terzi, 2011). Moreover, a number of countries, such as Mexico, Canada, Japan and India, have declared that they are powerfully going to adopt or converge with IFRS during the period from 2009 to 2011 (Harris et al., 2010). Recently, more than 100 jurisdictions in both developed and emerging countries around the world authorise the implementation of IFRSs (Guggiola, 2010).

Nevertheless, several researchers refer to the advantages of adopting IFRSs in the developing countries to increasing FDI (Tyrrall et al., 2007), others are concerned about the decision of which standards to choose, for a nation of IFRSs, usually depends on the culture (Briston, 1990; Larson, 1993; Askary, 2006), legal system, taxation, business organisations and ownership, as well as on the accounting profession within a country or a region. Libya is one of the emerging countries for which these standards could be either advantageous or detrimental to accounting practices, which can be considered as the result of two mechanisms: foreign companies, especially oil companies, and the accounting practicing system. In order to put the diffusion of the IAS/IFRS standards to Libyan companies into a clear perspective, the following sections provide a critical review of the IAS/IFRS adoption literature, highlighting the perceived IAS/IFRS standards lag and the gap between theory and practice.

\section{The Effects of IAS/IFRS Adoption on Financial Reporting Quality}

\subsection{Background and Developed IAS/IFRS Adoption}

The IAS was founded in 1975; since the IASC was published in 1973 to test high-quality accounting standards to be applied internationally (see Figure 1). As indicated by Whittington (2005), adoption of IFRSs in European states was the idea since 1973 when the IASC was established and its accounting history between accounting standard countries begins 1973. In 2000, there have been substantial changes in both IAS standards and the IASC organisational into the IASB. However, by 2001 the IASB stated to issue the IFRSs which are mandatory to be adopted at most international stock exchanges except the US which announced its desire to consider the IFRS and there is possibility that the US is going to adopt it as early as 2014 (IFRS website, 2010; Kinkela et al., 2010). In July 2002, the European Parliament voted to require that all listed companies in the EU apply IFRS starting in the year 2005/2007 and in September 2003 to Regulation (EC) 1725/2003 endorsing all standards IASs in interpretations (SICs) Standing Interpretations Committee standards in EU law, except IAS 32 and IAS 39 and related SICs 5, 16 and 17. On February 27, 2006, the 1ASB with the FASB have jointly issued documentation to confirming the shared objective of both boards to develop high quality accounting standards to be applied by the international stock markets. 


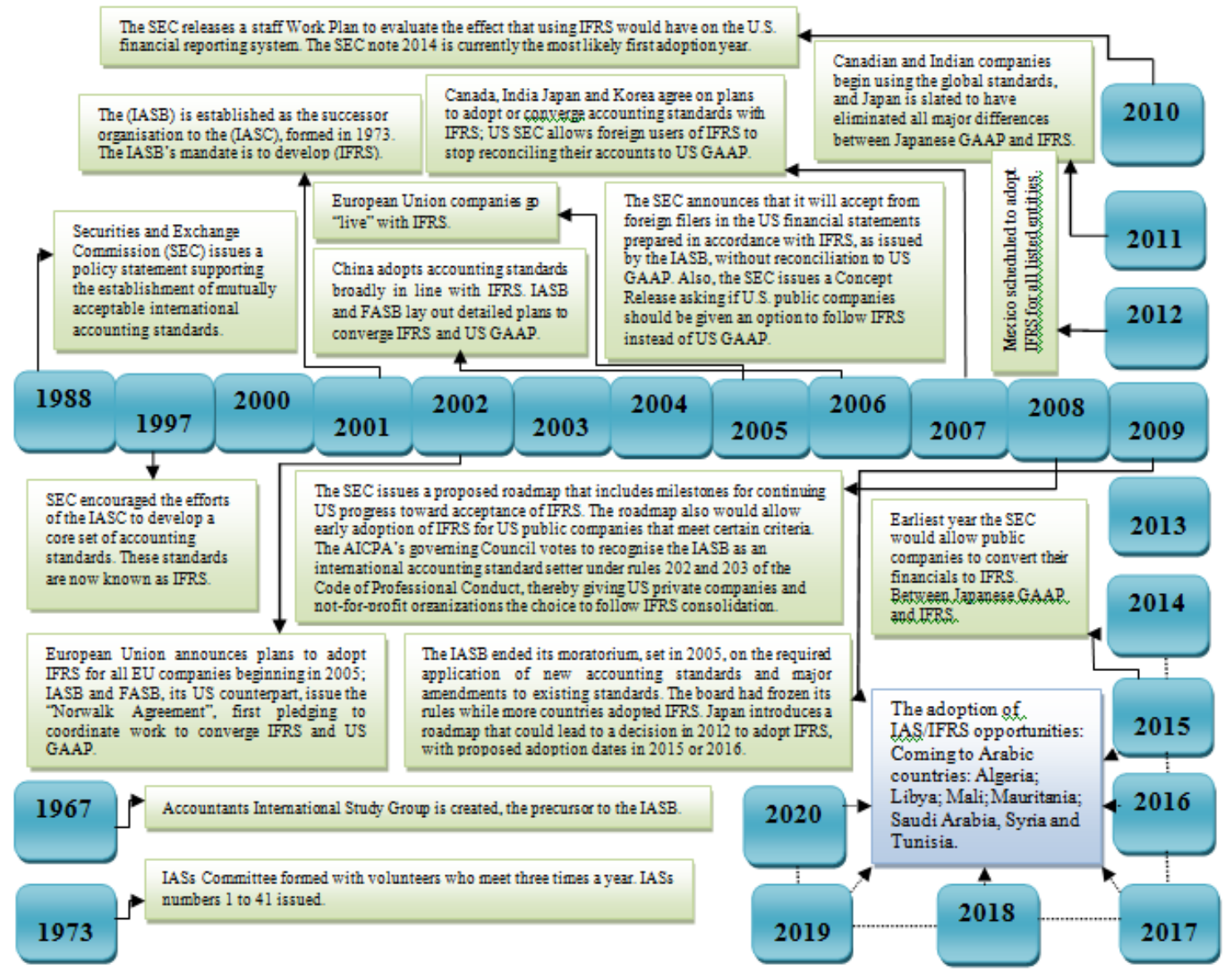

Figure 1. Timeline: IAS/IFRS adoption around the world.

Source: Adopted from IFRS website, 2010.

Adopting IAS/IFRS in EU provides a base for preparing financial statements which are more convergent and has pushed for higher levels of governance. Later, Schipper (2007) argues that the adoption of IAS/IFRS for international convergence between FASB and IASB in the EU countries provides a more powerful setting to test the determinants and economic influences of accounting quality due to accounting standards across EU companies are now the same. It is clear that with these developments and changes to increasing globalisation and to meet challenges posed by integration of international financial markets, every country tried to adopt the combined set of standards for international financial reporting. Libya like many emerging countries does not have codification of international financial accounting standards. Consequently, adopting IAS/IFRS standards will eliminate the cost of set up and creation of accounting standards.

\subsection{IAS/IFRS Adoption and Relevance of Key Accounting Quality}

The claim of higher information quality of IAS/IFRS adoption is founded on the higher-quantity of required disclosures as well as the supposed higher information applies to their different recognition and measurement rules affecting the accounting numbers. IAS/IFRS adoption that require higher levels of disclosure than local regulations which specifically applies to the Continental European countries with a French or German 
accounting font which can be considered generally accepted (Schrand and Verrecchia, 2002). Therefore, today it can be understanding to applies similarly to the business community (Caramis, 2002) and regulators (Van Hulle, 2003) as well as various academic studies have supported that when disclosure rules of these different reporting standards as actual disclosures in annual reports of firms applying local ISA/IFRS or GAAP (Born, 2002). Other studies have focused on the transitional goals of achieving comparability (Ball, 2001; Chen et al., 2002). For instance, Leuz et al. (2003) show that both investor protection laws and the enforcement of those laws are significant determinants of reporting quality, while Ball et al. (2006) highlight the importance of preparers' financial reporting incentives.

The high-quality accounting standards of Ball $(2001 ; 2006)$ indicate that there has been extraordinary success in developing and distributing a comprehensive establishing of high-quality IFRS standards. In this way, he concludes that we are able to measure the quality of the standards, not the quality the enforcement of the standard. While, researchers such as: Van Tendeloo and Vanstraelen (2005), Hung and Subramanyam (2007), Barth et al. (2008) who argue that high-quality accounting standards with IAS can improve the value relevance of their financial statement information. These studies suggest that IAS adoption is associated with development in accounting quality, that it is not still clearly evidence effective. Therefore, Barth et al. (2008) point out that any further progress in accounting quality for firms applying IAS may be attributable to changes in incentives and not to changes in the financial reporting system. Also, Ashraf and Ghani (2005) point out that adopting the IFRS in the developing countries will improve the quality of standards as well as reduce the expense and time of preparing the financial statements. While, Fearnley et al. (2010) argued that UK is required to use IFRS responding to the EU requirements, however, UK government should work hard to overturn it. Moreover, they claimed that even though IFRS did damage UK financial statements, UK accounting standards setters still aim to increase its burden on the companies, including small ones. Clarkson et al. (2011) however, find that IFRS adoption has failed to enhance financial reporting quality. In a study investigating 1,722 firms from nine European countries in which early IFRS adoption was not allowed.

Essentially, the argument is that the accounting quality after IAS/IFRS adoption joints on following factors: (a) the quality of the standards; (b) a country's legal and business environment; (c) higher levels of disclosure; and (d) financial reporting incentives. Since all EU countries will have consistent financial reporting rules, future improvements in accounting quality will be largely dependent on changes in a country's legal and business environment, higher level of disclosure, and financial reporting incentives. For instance, changing Libyan's whole institutional infrastructure is difficult, so addressing adoption of IAS/IFRS will perhaps be the achieving any further improvements in accounting quality with the following the goals: (a) organising rules; (b) improving the conditions of the accounting profession; (c) raising the standards of accountants; (d) auditors professionally; (e) academically, culturally and politically, and of organising and participating in conferences, and seminars related to accounting. 


\subsection{What the Benefits of IAS/IFRS Adoption}

Several academic researches, however, has found it difficult to provide thoroughly the perceived "benefits" and "activities" of the declared objectives of introducing IAS/IFRS when using data of firm's which already have adopted particular form of international reporting IAS/IFRS adoption. The EU policy requires that around 7,000 listed EU companies to report their results under IAS/IFRS by 2005 (with some exceptions by 2007), referred to this Regulation (EC) 1606/2002 of July 2002 which represents a most significant change in the nature and level requirement of EU reporting, since the start of the EU accounting harmonisation efforts and was considered an accounting revolution (Wagenhoer, 2003). Given that IAS/IFRS adoption considered as a key step towards the evolution of a global set of accounting standards.

On the academic level, however, most of the previous studies have been examining the intended benefits of IAS/IFRS adoption which can be classified into two groups. The first group of the analysis studies focuses on the transition and implementation of IAS/IFRS within the scope of local accounting systems (Harris et al., 1994; Niskanen et al., 2000; Arce and Mora, 2002; Haller and Eierle, 2004; Vellam, 2004; Jermakowicz, 2004; Shipper, 2005; Whittington, 2005; Agca and Aktas, 2007; Callao et al., 2007; Lantto and Sahlström, 2009; Gaston et al., 2010; Iatridis, 2010; Kabir et al., 2010). These studies generally use descriptive statistics, paired two-group tests (independent samples $t$ test for parametric data, Wilcoxon signed rank test for non-parametric data), and regression analysis. The second group investigates the financial reporting under IAS/IFRS with reference to the compliance to IAS/IFRS adoption (Harris et al., 1994; Emenyonu and Gray, 1996; El-Gazzar et al., 1999; Murphy, 1999; Street and Bryant, 2000; Ashbaugh, 2001; Glaum and Street 2003; Tarca, 2004; Cuijpers and Buijink, 2005) and the quality of information under IAS/IFRS of accounting information (Ashbaugh and Pincus, 2001; Van Tendeloo and Vanstraelen, 2005; Zeghal and Mhedhbi, 2006; Jermakowicz et al., 2007; Gaston et al., 2010; Jarva and Lantto, 2010; Zeghal et al., 2011; Barth et al., 2012).

Noteworthy, Barth et al. (2008) have examined the request of IAS in 21 countries over the period 1994-2003. They find that IAS firms higher accounting quality than firms applying DAS of voluntary adopters. However study of Papadatos and Bellas (2011) indicated that relation between mandatory implementation of IFRS and value relevance of accounting information may not be in the same direction for every firm since they stated that both firm size and fixed assets became significant factors in their study.

In their turn, Daske et al. (2013) who also find that market liquidity, and disclosure for firms increased around the time of the mandatory IAS/IFRS adoption. Armstrong et al. (2010) provide evidence that investors reacted positively to16 events related to the adoption of IFRS in Europe. Pope and McLeay (2011) examine the effects of mandatory IAS/IFRS adoption in the EU using limited data during the 2007-2010 period, and with a specific focus on findings from the European Commission-funded INTACCT network project. They find that the effects of mandatory IAS/IFRS adoption largely depend on preparer incentives and local enforcement. Clarkson et al. (2011) examine the impact of IFRS standards adoption in EU 


\section{MInstitute Macrothink $_{\text {Int }}$}

International Journal of Accounting and Financial Reporting ISSN 2162-3082

and Australia on the relevance of book values and earnings for equity valuation. They found that 3488 firms which initially adopted IFRS in 2005, found an increased non linearity in data subsequent to IFRS adoption, for firms in common law countries with nonlinear effects there is no observed change in price relevance for firms in either code law or common law countries. Additionally, they identified that relevance of firms numbers has increased after adopting IFRS.

Newness of an idea or practice should also be considered in terms of its adoption IAS/IFRS by developing countries/or emerging market (including Libya), is helpful in preparing accurate and fair financial statements, in which lead to easily and simply comparisons of financial statements to the ones prepared within, or outside these nations; as a results increasing accounting practicing through development-promoting in the economic, foreign investment opportunities will be facilitated, and the ability of raising capital from outside will enhanced.

\section{Research Framework, Scope and Methodology}

\subsection{Background of the Libya}

Libya is a rich developing country that is just beginning to change to a market-based economy, which attempting to rapidly move towards economic growth (Masoud, 2013a). Is located in the Middle East and North Africa region, a relatively small nation with a population of 6.155 million in 2012 (World Bank 2013a). It operates under a centrally planned economic model, and with plentiful oil reserves, enjoyed the latest value for GNI per capita of 16,800 in 2009 , being ranked $54^{\text {th }}$ in the world by The World Bank, with indicate income level Upper Middle Income as of GDP growth rate 2.1\% in 2009, which it's being classified as a 'developing' nation (World Bank, 2013b), however, with the revised establishment of a stock market June 3, 2006 (GPC Resolution 134), it could more accurately be categorised as an "emerging" market. Its natural resources, particularly oil revenue and natural gas have been exploited to such an extent that the revenues have helped a rapid and increasing its industrial base, radical development of the Libyan economy, without the expected transition through hypothetical development stages experienced by most industrialised countries, and in moving into the global capital market arena (Masoud, 2014).

During the early 1990s for instance, Libya launched a market-based system which transformed it from being centrally planned as the public sector grew under the umbrella of socialist transformation and bureaucratic procedures controlled by laws and resolutions issued during the early 1970s and late 1980s. Prior to the transition period companies were predominantly owned, controlled and supervised by government institutions. This transition, however, will pose significant challenges for the country's accounting profession. The accounting profession in Libya is still in its infancy and its main emphasis is on preparing external financial reports and external auditing which is mainly imposed by the laws rather than driven by the desire to provide useful information to potential users (Bait-El-Mal et al., 1973; Kilani, 1988; Buzied, 1998).

In the following years, the deterioration in the political relationship between the Libyan 
government and the West, especially the US, culminated in a ban on the import of Libyan oil and the export to Libya of US oil industry technology in 1982 and the UN economic sanctions in 1992. This situation caused political and economic isolation of Libya for most of the 1990s. Since the start of the 2000s relations with the West have been gradually normalizing, ending the UN embargo in 2003, and the US embargo in 2004. As a result, numerous foreign companies have resumed operating in Libya in the 2000s and early 2004s. In order to optimise the contribution relevant and reliable accounting practices that were apply to improve the quality of accounting profession and accounting education, which should be well trained, organised, and evaluated. A study of historical factors that have affected Libya's accounting profession indicates that is not included in the scope of responsibilities undertaken within government controlling rules and business.

\subsection{The Growth of Accounting Standards in the Libya over the Period}

The country witnessed the start of the evolution of accounting at some meaningful level during the period between 1911 and 1951 was the period of Italian and British occupation of Libya (Kilani, 1988). In 1951 at time of independence, there was no domestic accounting professional and most of the business firms depended upon foreign accounting firms from Italy and the UK. For instance, the Libyan Commercial Code (LCC), which was issued in 1953/1970, and the Libyan Income Tax Law (LITL) of 1973, requires companies to prepare an annual report, including an income statement and a balance sheet. In this context, LITL had affects, the accounting practice in Libya, through influence on the financial reporting rules and practices. According to Hung and Subramanyam (2007) IFRSs are independent of tax reporting considerations. It is clear that with existing regulation framework of high-quality accounting in Libya have to modify in order to horizontal implementation of IAS/IFRS.

Furthermore, following the oil discovery several American companies began expanding their investments in Libya, and as a result of a lack of regulations or set rules for the accounting profession in Libya, these companies adopted and applied their own accounting systems, coupled with (AAAPs) American Accepted Accounting Principles (Bait El-Mal et al., 1973). In the early 1960s, discovery of oil which provided the country with financial resources to significant growth of the economy, and due to the increase of accounting firms in quantity and capacity, and the spread of irregularities in the practice of accounting and auditing, there was an urgent need for issuing laws to administrate accountancy and related areas, and creation of professionally organised body to take responsibility of developing a common outline for accounting and auditing. According to the Chairman of the IFRIC, Robert Garnett pointed out: "with oil revenues being directed into large investments, the region is increasingly being seen as a potential partner [...]", (Edrey and Greggi, 2012). The history of Libya under the Gaddafi regime extended for a period of forty-two years, from 1969 to 2011. 


\section{MInstitute ${ }_{\text {Ink }}^{\text {Macrothink }}$}

International Journal of Accounting and Financial Reporting ISSN 2162-3082 2014, Vol. 4, No. 1

In this respect, the Libyan Accountants and Auditors Association (LAAA) was established in June 1975 by the law no. 116 in 1973, with the aim of organising rules and improving the conditions of the accounting profession were codified in the regulations of Accountants' Act 1973. With the play-acting of the Accountants' Act 1973, all members of the profession are called Certified Public Accountant (CPA). LAAA, however, has been failed to achieve its objectives of holding and participating in activities as following: (a) organisation and participating in conferences and seminars related to profession, including academically, culturally and politically; (b) organising and improving the conditions of the accounting profession and raising the standards of accountants and auditors professionally; (c) increasing co-operation between its ambers and protecting their rights; (d) establishing a retirement fund for its members. Hence environmental factors that have influenced the development of the Libyan accounting profession include the presence of foreign companies and international accounting firms that came to Libya after the country's independence in 1951, particularly from the UK and the US, which contributed to the development of accounting in Libya through the transfer of accounting knowledge and practice from their countries of origin to Libyan workers.

In 1997, the Libyan Foreign Investment Board (LFIB) was established by Act 5 to attract foreign investment into Libya within a socialist framework of economic and social development. LFIB in 2003 were aimed at promoting foreign investment through a partnership (joint venture) between Libyan and foreign capital in different sectors such as industry, health, agriculture, and tourism. Likewise, Libya membership of International Federation of Accountants (IFAC) body compliance program, which has been fully developed their GAAP principles, and are akin to encourage their companies to follow the adoption of IAS/IFRS. The argument is that, gap, tracing the historical development of the accounting profession in Libya prior to its becoming an emerging economy. This enables an informed explanation of current practice, including the accounting field system, and makes possible the identification of specific challenges the Libyan accounting profession and accounting education faces in the future, if it is to assist Libya in reaching its economic goals and establish a new IAS/IFRS adoption.

\subsection{Key Accounting Differences between Libyan Accounting System Gap and IAS/IFRS Adoption}

As a result of globalising forces, many developing and emerging countries have adopted the accounting systems of western developed countries. IAS/IFRS adoption in the EU is an example of accounting standardisation among countries having different conceptual frameworks and enforcement rules. Empirical findings show that the quality of IAS/IFRS implementation and the economic significances of their adoption depend on enforcement mechanisms and institutional factors, which are far from uniform across EU countries. This is a key issue given the widespread acceptance of IAS/IFRS all over the world. A number of countries are early pioneers in this accounting globalisation process, while others are still hesitating or even have reservations of using it. For instance, Ramanna and Sletten (2010) find that countries with less power, low opportunity cost of domestic standards, close proximity to IFRS setters are more willing to adopt IFRS standards. However, they do not 
find that the level of foreign trade investment in a country affects the adoption decision, which is not consistent with the general notion that IFRS standards lowers information costs in global economy.

Hope et al. (2006) results suggest that adopt IFRS standards is a mechanism through which countries that provide better access to improve investor protection and create their domestic capital markets more accessible to foreign investors. In Jordan, Al-Akra et al. (2009) have analysed the impact of economic, political, legal and cultural factors on promoting the accounting practices. They conclude that the political and economic factors are the elements which most contribute to this development. Indeed, while the study of Gray (2oo1) However, states that cultural differences based on Hofstede's model are the key cause of such difference between the accounting systems. Moreover, Radebaugh et al. (2006) indicated that the variation among countries is affected by the outcomes' needed in these countries. Thus the differences are not between developed and emerging economic, but are also between the countries that share a similar culture. Nobes (1998) argues that economic and institutional differences are the main reasons for the diversity between accounting systems.

Libya, like any emerging countries, possesses historic and environmental factors that substantially differ from the environmental factors in the developed countries particularly the western countries (Kilani, 1998; Bakar and Russell, 2003). By any potential framework cultural, it must be acknowledged that Libya, as a Middle Eastern Arab nation, has unique factors that have affected its accounting profession. The UK and US-influenced Libyan accounting profession (Kilani, 1988) is not well developed (Bengharbia, 1989; Selway, 2000), reinforcing the cultural problems associated with the adoption of imported systems. In this respect, it has been argued that the factors which have influenced the adoption of accounting practices in Libya are multinational companies, especially in the oil sector, international accounting firms (mainly from the UK and the US), the accounting education system which relies on British and American texts, the accountants from other countries, and the Libyan accountants educated overseas (Saleh, 2001; Mahmud and Russell, 2003). Thus, the diffusion of Western accounting practices in Libya can be linked to two key mechanisms: foreign companies, especially the oil companies operating in Libya, and the Libyan accounting education system.

This raised an interesting possible role for IAS/IFRS adoption. If Libyan financial accounting is not well adapted to the Libyan context, perhaps the new IFRS could fill any gap between financial accounting and the users' needs which, in the Libyan context, might be different from EU users. It is therefore useful to understand the background and interesting to bear in mind what accounting information companies actually do provide in practice and, especially, what users think of corporate accounting practices and would like to happen in the future.

\subsection{General Impacts of IAS/IFRS Adoption in Libya}

To date, there is no exhaustive literary review examining the effects of the adoption of IAS/IFRS frameworks in the Libyan accounting. The Key scopes of these impacts are relevance of accounting numbers, accounting quality, transparency, fair value accounting 


\section{Mll Macrothink}

International Journal of Accounting and Financial Reporting ISSN 2162-3082 2014, Vol. 4, No. 1

practices, improvements in financial ratios, book value of equity and earnings, comparability, and improved analyst's forecasts. As IAS/IFRS adoption introduced in EU the regulatory has change not only shifted the national accounting regulation, but it has also created some effects for the overall international convergence of financial reporting. Ball et al. (2003), Ashraf and Ghani (2005), Daske (2006), and Azzali et al. (2008) who find that the mere adoption of IFRSs does not achieve the desired improvement of the quality of accounting information.

In Czech Republic, Sucher and Jindrichovska (2004) confirm the problems of implementing IAS/IFRS by analysing the key issues that arise by moving to IAS/IFRS reporting. Their study emphasises that even though the Czech accounting system is moving closer to IAS/IFRS in some areas such as the valuation at fair value, which that need from national system to keep the tax and financial reporting separate to ensure that the different objectives of the two reporting systems are met clarifies why the Czech system differs in certain aspects from IAS/IFRS. Jermakowicz (2006) highlights the benefits of fulfilling with IAS/IFRS in Belgium by all listed and non-listed companies to identifying and describing the key differences between IAS/IFRS and local GAAP conceptual framework, with reference to the link between tax and financial accounting by measuring the main impacts on the change to IFRS. The results shows that the major differences between the two set of standards are linked to the tax nature of Belgian accounting rules and the inadequate implementation guidance that creates a risk of a different interpretation of IAS/IFRS.

Haller and Eierle (2004) show that the implementation of IFRS rules requires a thorough change of the German accounting system in accordance with international accounting principles (IAS/IFRS or US GAAP), and that such a reform requests a step-by-step revision to make the process of transition to IAS/IFRS fast and easy, but slow and conservative. Paananen and Lin (2009) find a decline in accounting quality after mandatory adoption using a sample of German companies. Gjerde et al. (2008) find little evidence of increased value relevance after adopting IFRS in Norway. Moreover, Hope et al. (2006) and Ramanna and Sletten (2010) studies do not find consistent results on whether the IFRS adoption would reduce information cost and hence make capital markets more accessible. AS for Hussain et al. (2002) claim that IFRSs do not pay any attention to Islamic law (Shari'a). As a result, the Shari'a and IFRSs cannot be combined easily. In Egypt, Samaha and Dahawy (2011) have find that the level of compliance with international standards is affected by the conflict between local laws and these standards.

However, several studies such as: Harris and Muller (1999) identified the market valuation of earnings and the book values of financial statements in accordance with IFRS and US-GAAP. They find that, IFRS earnings per share amounts were identified to be more highly associated with prices per share than US-GAAP earnings per share amounts. In Finland, Lantto and Sahlström (2009) acknowledged the IFRS transition effects on financial reporting with the use of financial ratios. They observed that the selected financial ratios were significantly affected as a result of the IFRS adoption, in which fair accounting rules and other important rules were the reasons of these important fluctuations. Study of Kabir et al. (2010) examined the effects of IFRS adoption on accounts and earnings' quality of New Zealander companies. 


\section{Mll Macrothink}

International Journal of Accounting and Financial Reporting ISSN 2162-3082 2014, Vol. 4, No. 1

They identified that total assets, total liabilities and net profit figures were higher in IFRS-based financial statements. They also concluded that IFRS-based adjustments increased goodwill, other intangible assets and investment property amounts. Alternatively, these adjustments caused decreases in employee benefits and share-based payments. Similarly, Iatridis and Rouvolis (2010) provided that IFRS adoption leads to more value relevant ccounting measures in Greece Stock Exchange for 254 firms. In French, Zeghal et al. (2011) considered the effects of IFRS adoption on earnings management of French companies. They find that, mandatory IFRS adoption caused a reduction in the earnings management level. Furthermore, they identified that some factors affected the IFRS adoption of French companies.

It can be argue that this is an important feature of this study because it is well known that the adoption of IAS/IFRS frameworks in the Libyan accounting does not benefit all firms in a uniform way. Therefore, the adoption of IAS/IFRS will be associated with some difficulties and costs may apply more to small companies and local accounting firms through to the stock markets. However, existing environmental factors in the developing countries may impede the possibility of applying the success of the adoption of IAS/IFRS appropriately and thus hold back accounting harmonisation. Therefore, the most significant accounting structure background should accompany the adoption of that the quality of IAS/IFRS must be understandable.

\subsection{Lessons for Changes}

Libya is a developing country and it has a unique culture, as any other country, with a significant position as the second largest oil producer in Africa. The rapid developments and changes in the Libyan economy and its increasing integration with the global economy, make it an excellent site for the investigation of the important aspects of the responsiveness (or not) of accounting practicing to its environment. Therefore, this is a good opportunity to undertake research on IAS/IFRS adoption in Libyan companies in the context described previously. Therefore, If Libya is going to adopt IAS/IFRS standards it as early as possible may be attract considerable attention from regulators, investors, companies, practitioners, and academics worldwide including other benefits.

The adoption of IAS/IFRS has become the new phenomenon during the past eight years. Libya, Algeria, Egypt, Tunisia, Jordan and Saudi Arabia, akin to most developing countries, shared similar experiences whilst striving to achieve the stabilisation of their economies. They did so because they found themselves incapable of earning sufficient foreign exchange to protect their currencies. Indeed, many of these nations began transforming their situations from socialist, state-owned entities to market-based economies (Frances and Garnsey, 1996). According to this view, as with the adoption of IAS/IFRS may be useful for decision-making, as this study suggest that the quality of financial reporting, regulatory and level of disclosure will improvement. In addition, it is affected by the education levels of users and their lack of knowledge of IAS/IFRS adoption.

Leasing from other experiences countries, however, provided opportunities for the introduction of managerial and technical skills that would allow the use of knowledge, ability 
and vitality value in a more efficient way within the lease duration. Libya, therefore, is developing an economic policy to improve accounting management of the most productive public enterprises and privatised ownership enterprises to address the high- quality accounting practices. The primary challenges facing Libya's are discussed. This is followed by an explanation of the outcomes of the framework of the dominants for adopting IAS/IFRS standards via country characteristics related to fundamentals target. Therefore, it should think that even after the adoption of IAS/IFRS, this objective may still be questionable.

\subsection{The Main Obstacles to a Sound and Implantation of IAS/IFRS Adoption in Libya}

According to Yapa (2003) indicates that one of the elements that might be considered as an obstacle to harmonising accounting standards is the professional accounting bodies, wherein the IASB requires a strong effort to implement the accounting standards effectively. In this way, Mir and Rahaman (2005) point out, the most problematic aspect of the adoption of the international standards relates to the process of adoption rather than to the content of the individual accounting standards or to the decision to adopt. In the same context, Barth et al. (2008) argue that the effects of features of the financial reporting framework other than the standards themselves could eliminate any improvement in accounting quality arising from higher quality accounting standards. This study could explain the key issue why the implementation of a new accounting regime is not known and understood by local and foreign companies. Nonetheless, there remains much for this IAS/IFRS adoption to do before it can yield fruit due to numerous obstacles should be identified and address in order to ensure horizontal implementation to benefit fully from the application of IAS/IFRS adoption in Libya. The following were identified as the most significant of these limitations and obstacles:

1. Difficulty of prediction and domination of uncertain circumstances, owing to the issue of many rules and regulations without feasibility studies being conducted.

2. Reliance on some particular system of governmental laws and regulations, national economies often vary in terms of their legal systems. They may rely on either a common-law; code-law system or shareholder; or they may have protective legislation, such as unfair trade and antitrust laws.

3. Taxation: IAS/IFRS adoption will create problem. How do taxation laws address the treatment of tax liabilities arising from on convergence from Libya GAAP to IAS/IFRS adoption. Where this is not taken care of, it would duplicate.

4. State of business complexity: national economies can vary in terms of their technological and industrial know-how, which can create differences in both business needs and business output.

5. The weakness of financial reports and appropriate auditing standards within deficiency of national accounting systems.

6. The weakness of public awareness frameworks of the role of investment, and the role of the stock market in the whole economy. 


\section{Macrothink}

International Journal of Accounting and Financial Reporting

7. Libyan privatised companies were valued by unfair evaluation techniques due to the loss of basic trading information.

8. Lack of efficiency and development of technical skills, and inadequate knowledge of the Libyan professional accountants to be understandable in order to adopt a key feature of the new applicable IFRS models.

9. The short and long-term investments opportunities for Libyan companies are hindered.

10. The accounting technology impact and know-how imported from other countries influence of accounting practices and the writings and contributions of academics and practitioners in the accounting field.

\section{Conclusion}

The key issue in the implementation IAS/IFRSs is timing. Regarding the usefulness of adopting IAS/IFRSs in the context of decision making, it appears from the findings that there is overall agreement that financial quality reporting based on IFRSs may be useful for decision-making. As with the adoption of IAS/IFRSs with particular references to Libya, the study suggests that: increasing the level of comparability and provide more reliable, accurate, transparency and valid quality of financial accounting information including benefit the quality of financial reporting and level of disclosure will improve. Hence the change from local accounting standards to IAS/FRS adoption is not an easy task as some might think, since if we are to succeed. In many countries the gap between local accounting and IFRS standards is very big in short run. Therefore, this change comes at a time when the IFRS themselves are going through major changes to address issues identified by users of the standards and to cover certain weakness of its accounting infrastructure that were previously not passably addressed by standards. However, the practice of implementing IAS/IFRSs in Libya will face several obstacles including lack of technical skills, training and inadequate knowledge of Libyan professional accounting, the difficulty to develop it existing high-quality accounting systems, amongst disclosure reports, and a regulatory framework to cope with economic and social development, and training of effective accounting.

\section{Contribution to Knowledge}

This study seeks to make an original contribution to knowledge by provides an important introduction to this area and has attempted to explore its significance for the high- quality accounting practices. A critical review of this research has added to the existing body of literature and assists the researcher in obtaining new ideas and perspectives, exploring the significant adoption of IAS/IFRS related to high- quality accounting practices and economic growth in the following areas.

1. This is one of the first studies of its type in this critical area in Libya. It is hoped that such contributions will be beneficial, both academically and professionally. Academically, this research aims to focus attention upon a neglected area in the context of the adoption of IAS/IFRS. Professionally, managers will further seek out 


\section{1ll Macrothink}

International Journal of Accounting and Financial Reporting ISSN 2162-3082 2014, Vol. 4, No. 1

the practical implications offered by this study in their actual relationships with their accounting practices.

2. Most of the studies on the adoption of IAS/IFRS have been conducted in developed countries, while studies considering IAS/IFRS in emerging and transitional economies are still scarce (including Libya). Moreover, previous studies of IAS/IFRS adoption in developing countries presented their findings without the help of an appropriate theoretical framework and in very few cases through IFRS standards approach. Therefore, this study contributes to knowledge for the first time, a multitude of factors that affect the adoption of IAS/IFRS in one of the developing countries, currently in a period of transition to a market economy.

3. Most of the previous studies in developing countries are descriptive, reporting the adoption tolls of IAS/IFRS, without any further analysis to find out the factors that influence (facilitate or hinder) the change or the diffusion of IAS/IFRS in these countries.

4. As discussed in early, this study's framework extends IAS/IFRS adoption the one developed by EU experiences which proposes different perspectives in explaining the diffusion of origination, namely efficient choice perspective, fad, fashion and forced perspectives. Efficient choice perspective could represent the demand side of diffusion (or economic pressure according to EU Regulation 1606/2002), whereas fad, fashion and forced perspectives are based heavily on new established IAS/IFRS adoption.

5. Given the dearth of theoretical framework adoption of IAS/IFRS in Libya, it is hoped that the findings of this study will not only make a theoretical contribution but also make researchers and managers aware of the current state and development of IAS/IFRS in Libyan business companies and thus contribute to a better understanding of these techniques in the emerging and transitional countries and reduce the lag in the diffusion of IAS/IFRS adoption among countries. It also provides significant insights into the role of institutions (e.g. academic institutions) and foreign companies, in the diffusion of IAS/IFRS adoption in developing countries.

Based on the research outcomes, some study policy and recommendations are suggested in adoption of IAS/IFRS in Libya. In light of the study findings, the researcher recommends include:

1. Work should be undertaken to increase awareness among the preparers and auditors of financial reports of listed companies in the Libyan stock market with respect to the accounting practices through workshops, courses and seminars dealing with this subject, and to encourage these parties to follow IFRS adoptions.

2. It is important to raise the level of coordination and interaction between universities, educational and training institutions and between companies listed in the Libyan stock market, and to bind the application of high- quality accounting practices in order to blend theoretical knowledge with the practical experience of workers in these 


\section{Macrothink}

companies.

3. To improve the awareness of the importance of corporate social information, regulation policy and its disclosure, Libyan companies should be encouraged to publish their annual reports to a wider set of audiences, including government department and agencies, employees, consumers, local communities and society.

4. Companies should present natural resource conservation information in a section of the annual report preferably entitled 'social responsibility' in a form that is easy to understand, for both internal and external stakeholders. Moreover, the companies should give all stakeholders the right to access the company's information at any time, which would increase the company's transparency. This should be achieved through a greater awareness on the part of the accounting profession, the accounting education system, the legal requirements, governmental bodies and the media.

5. The accounting program of Libyan universities and colleges should be adapted in a way that includes the social role of accounting, corporate social reporting and regulation policy in Libya. The academics in the accounting field who work in Libyan universities and colleges can also affect the corporate reporting and disclosure practices in a country by carrying out research and entering into a dialogue with practitioners and official concerned.

\section{Limitations and Future Research}

This study however, as any other study of this kind of research, it is subject to a number of limitations. Keeping in mind the following limitations, this study should merely be perceived as a contribution to continue the adoption of IAS/IFRS in emerging economy research process in Libya and not as an end in itself. The limitation of this research can be achieved and discussed below:

1. The major complexity with this study is that no studies have been previously performed regarding the implementation of adoption of IAS/IFRS influencing the accounting practicing in the Libyan context. This would add to the originality and value of this study, as this study will not have the added benefit of learning from others' mistakes.

2. There was a lack of literature concerning the adoption of IAS/IFRS in Libya in particular, and other MENA nations in general. Most of the available literature was related to developing countries including Eastern Europe, Latin America and developed countries for example, UK and US.

3. There was a scarcity of empirical work previously conducted in the study area. This meant a lack of scales and measurements that could be used in order to establish a cause and influence study to examine the relationship between accounting practices and adoption of IAS/IFRS. Additionally, most of the available studies revealed contentious findings that do not encourage future research, as hitherto mentioned. 


\section{Outline for Further Research}

The limitations mentioned above, and other thoughts discussions of this study, which would need much empirical work to be done. The following are suggested areas for future research:

1. To the best of the researcher's knowledge, this study is one of the first studies discussed the issue of impairment in Libya. To validate the conclusions of this study, further comprehensive research is required into the foreign companies has a significant impact on the diffusion of improvement. In addition, a joint undertaking with foreign partner offers an opportunity to copy the foreign partners' techniques (fad factor) or to work under a foreign partner pressure (involuntary factor) or a mixture of these factors. Thus, the area that seems to be promising for feature research is the examination in detail of the nature of the role of foreign companies on the diffusion of adoption of IAS/IFRS in developing countries.

2. Due to the lack of high-quality published databases, this study uses secondary data, which were based on a literature review and on original archival research from other countries especially US, UK and European countries is reviewed. Although, further study can adapted and developed survey (questionnaire and interview) from prior studies. In other words, this triangulation method will provide a better explanation of the relationship between high- quality accounting practices and framework adoption of IAS/IFRS in Libya.

3. Future research could expand the framework of this study, as more data becomes available in future, such material can be used for testing and identifying additional variables that could have influence on adoption of IAS/IFRS and, therefore, more long-term research is needed in order to investigate the determinants of IFRS standards over an extended period of time. Furthermore, study of the proposed model in other emerging countries could be performed in order to raise further explanation of the model and to reveal more generalised findings.

4. It would be particularly interesting to discover what are the new IFRS effects on the developing countries accounting practice (including Libya)? Does the adoption of IAS/IFRS have an effect on these countries' economies? Finally, does the content of some IFRS really enable to improve high- quality accounting information and disclosure?.

\section{References}

Agca, A. and Aktas, R. (2007). First time application of IFRS and its impact on financial ratios: a study on Turkish listed firms. Problems and Perspectives in Management, 5(2), 99-112.

Al-Akra, M., Jahangir, A.M. and Marashdeh, O. (2009). Development of accounting regulation in Jordan. The International Journal of Accounting 44, 163-186.

Arce, M. and Mora, A. (2002). Empirical evidence of the effect of European accounting differences on the stock market valuation of earnings and book value. The European 
Accounting Review 11(3), 573-599.http://dx.doi.org/10.1080/09638180220125616.

Armstrong, C., Barth M., Jagolinzer, A . and Riedl, E. (2010). Market reaction to the adoption of IFRS in Europe. Accounting Review, 85(1), 31-61.

Ashbaugh, H. and Pincus, M. (2001). Domestic accounting standards, international accounting standards, and the predictability of earnings. Journal of Accounting Research $39(3), 417-434$.

Ashraf, J. and Ghani, W.I. (2005). Accounting development in Pakistan. The International Journal of Accounting 40(2), 175-201.

Azzali, S., Fornaciari, L. and Pesci C. (2010). The value relevance of the performance of listed Italian companies following the introduction of the IAS/IFRS, paper presented at the $4^{\text {th }}$ edition of the Annual International Conference Globalization and Higher Education in Economics and Business

Administration (GEBA), Alexandru Ioan Cuza University, Iasi, Romania, 21-23 October.

Bait-El-Mal, M.M. (1990). The significance and advancement of accounting information for economic development. Journal of Economic Research 2(2), 25-36.

Bait-El-Mal, M.M., Smith, C.H. and Tailor, M.E. (1973). The development of accounting in Libya. International Journal of Accounting, Education and Research 8(2), 83-101.

Bakar, M. and Russell, A. (2003). The development of accounting education and practice in Libya.

Research in Accounting in Emerging Economies. In Wallace, R.S.O., Samuels, J.M., Briston, R.J. and S.M. Saudagaran. Oxford, Elsevier Science 5, 197-236.

Ball, R. (2001). Infrastructure requirements for an economically efficient system of public financial reporting and disclosure. Brookings-Wharton Papers on Financial Services, 127-169.

Ball, R. (2006). IFRS: Pros and cons for investors. Accounting and Business Research, International Accounting Policy Forum 36(1), 5-27.

Ball, R., Ashok, R. and Sadka, G. (2006). Are timeliness and conservatism due to debt or equity markets? An international test of "contracting" and "value relevance". Theories of Accounting University of Chicago, USA.

Barth, M.E., Landsman, W.R. and Lang, M.H. (2008). International accounting standards and accounting quality. Journal of Accounting Research 46, 467-498.

Barth, M.E., Landsman, W.R, Lang, M.H. and Williams, C. (2012). Are IFRS based and US GAAP-based accounting amounts comparable?. Journal of Accounting and Economics 54(1), 68-93.

Bengharbia, S. (1989). Auditing and profession ethics in Libya. Journal of Economic Research, National Institute for Scientific Research: The Economic Research Center, 
Benghazi 1(1), 117-126.

Born, K. (2002). Rechnungslegung International: Konzernabschlüsse nach IAS, USGAAP, HGB und EG-Richtlinien. Auflage,Stuttgart.

Briston, R.J. (1990). Accounting in developing countries: Indonesia and the Solomon Islands as case studies for regional cooperation. Research in Third World Accounting 1, 195-216.

Buzied, M. (1998). Enterprise accounting and its context of operation: The case of Libya. Unpublished Ph.D. Thesis, University of Durham, UK.

Callao, S., Jarne, J.I. and Lainez, J.A. (2007). Adoption of IFRS in Spain: Effect on the comparability and relevance of financial reporting. Journal of International Accounting, Auditing and Taxation 16(2), 148-178.

Clarkson, P., Hanna, J.D., Richardson, G.D. and Thompson, R. (2011). The impact of IFRS adoption on the value relevance of book value and earnings. Journal of Contemporary Accounting and Economics 7(1), 1-17.

Caramis, C.V. (2002). The interplay between professional groups, the state and supranational agents: Pax Americana in the age of "globalisation". Accounting, Organizations and Society 27,379 - 408.

Chen, S., Sun, Z. and Wang, Y. (2002). Evidence from China on whether harmonized accounting standards harmonize accounting practices. Accounting Horizons, 16(3), 183-198.

Cuijpers, R. and Buijink, W. (2005). Voluntary adoption of non-local GAAP in the European Union: A study of determinants and consequences. European Accounting Review 14(3), 487-524.

Daske, H. (2006). Economic benefits of adopting IFRS or US-GAAP - have the expected cost of equity capital really decreased?. Journal of Business Finance and Accounting 33(3/4), 329-373.

Daske, H. and Gebhardt, G. (2006). International financial reporting standards and experts' perceptions of disclosure quality. Abacus 42 (3-4), 461-498.

Derwish, B.M.A. and Elghli, A.A. (2006). Effecting factors in developing accountancy in Libya.

Dirasat in Economics and Business 25, 1-11.

Dumontier, P. and Raffournier, B. (1998). Why firms comply voluntarily with IAS; an empirical analysis with Swiss data. Journal of International Financial Management and Accounting, 9(3), 216-245.

Edrey, Y. and Greggi, M. (2012). Tax law and the Mediterranean area. Lulu.com.

El-Sharif, Y. (1980). An Empirical investigation of Libyan professional accounting Services. Dirasat in Economics and Business XVI(1,2), 3-11. 


\section{Macrothink}

International Journal of Accounting and Financial Reporting ISSN 2162-3082 2014, Vol. 4, No. 1

Emenyonu, E.N. and Gray, S.J. (1996). International accounting harmonization and the major developed stock market countries: An empirical study. The international Journal of Accounting 31, 269-279.

Fearnley, S., Hosking, J. and Evershed, P. (2010). UK accounts lack proper scrutiny; letter to the editor. Financial Services Authority, Ed., 1, National Edition, (July, 2010).

Frances, J. and Garnsey, E. (1996). Supermarkets and suppliers in the United Kingdom: System integration, information and control. Accounting Organisations and Society, 21, 591-610.

Gaston, S.C., Garcia, C.F., Jarne, J.I. and Gadea, J.A. (2010). IFRS adoption in Spain and the United Kingdom: Effects on accounting numbers and relevance. Advances in Accounting, Incorporating Advances in International Accounting 26, 304-313. http://dx.doi.org/10.1016/j.adiac.2010.08.003.

Gjerde, O., Knivsfla, K. and Saettem, F. (2008). The value-relevance of adopting IFRS: Evidence from 145 NGAAP restatements. Journal of International Accounting, Auditing and Taxation 17(2), 92-112.

Glaum, M. and Street, D.L. (2003). Compliance with the disclosure requirements of Germany's New

Market: IAS versus US GAAP. Journal of International Financial Management and Accounting 14, 64-100.

Gray, R. (2001). Thirty years of social accounting, reporting and auditing: What (if anything) have we learnt?. Business Ethics: A European Review, 10(1), 9-15.

Guggiola, G. (2010). IFRS Adoption in the E.U., accounting harmonisation and market efficiency: A review. International Business and Economic Research Journal 9(12), 99-112.

Hail, L., Leuz, C. and Wysocki, P. (2010). Global accounting convergence and the potential adoption of IFRS by the U.S. (part I): Conceptual underpinnings and economic analysis. Accounting Horizons 24, 355-394.

Haller, A. and Eierle, B. (2004). The adaptation of German accounting rules to IFRS: A legislative balancing act. Accounting in Europe 1, 27-50.

Harris, P., Kinkela, K. and Malindretos, J. (2010). Introducing IFRS in introductory financial accounting courses. Business Education and Accreditation 2(1), 39-48.

Harris, M. and Muller, III.K. (1999). The market valuation of IAS versus US-GAAP accounting measures using Form 20-F reconciliations. Journal of Accounting and Economics 26(1), 285-312.

Harris, T., Lang, M. and Moeller, H.P. (1994) The value-relevance of German accounting measures: An empirical analysis. Journal of Accounting Research 32(2), 187-209.

Hope, O., Jin, J. and Kang, T. (2006). Empirical evidence on jurisdictions that adopt IFRS. 
Journal of International Accounting Research 5, 1-20.

Hung, M. and Subramanyam, K.R. (2007). Financial statement effects of adopting international accounting standards: The case of Germany. Review of Accounting Studies 12(4), 623-657.

Hussain, M., Islam, M.M., Gunasekaran, A. and Maskooki, K. (2002). Accounting standards and practices of financial institutions in GCC countries. Managerial Auditing Journal, 17(7), 350-362. http://dx.doi.org/10.1108/02686900210437453.

Iatridis, G., (2010). IFRS adoption and financial statement effects: The UK case. International Research Journal of Finance and Economics (38), 165-172.

Iatridis, G. and Rouvolis, S. (2010). The post-adoption effects of the implementation of international financial reporting standard in Greece. Journal of International Accounting, Auditing and Taxation 19(1), 55-65.

IFRS Foundation. (2010). Revised Constitution March. IFRS Foundation. Available at:<http://www.iasplus.com>.

Jarva, H. and Lantto, A.M. (2012). Information content of IFRS versus domestic accounting standards: Evidence from Finland. The Finnish Journal of Business Economics 2, 141-177.

Jermakowicz, K. (2006). Implanting IFRS from the perspective of UE publicly traded company. Journal of International Accounting Auditing and Taxation 5,170-196.

Jermacowicz, E.K., Prather, J.J. and Wulf, I. (2007). The value relevance of accounting income reported by DAX-30 German companies. Journal of International Financial Management and Accounting 18(3), 151-191.

Kilani, K.A. (19880. The evolution and status of accounting in Libya. Unpublished Ph.D. thesis, Hull University, UK.

Lantto, A. M. and Sahlström, P. (2009). Impact of international financial reporting standard adoption on key financial ratios. Accounting and Finance 49, 341-361. http://dx.doi.org/10.1111/j.1467-629X.2008.00283.x.

Larson, R.K. (1993). International accounting standards and economic growth: An empirical investigation of their relationship in Africa. Research in Third World Accounting 2, 27-43.

Leuz, C., Nanda, D. and Wysocki, P. (2003). Earnings management and investor protection: An international comparison. Journal of Financial Economics 69(3), 505-527.

Mahmud, M.B. and Russell, A. (2003). An empirical investigation of the development of accounting education and practice in Libya, and of strategies for enhancing accounting education and accounting practice in Libya. Research in Emerging Economies 5, 197-236.

Masoud, N. (2013a). Libya's step towards change. Journal of World Economic Research 2(4), 75-81. http://www.sciencepublishinggroup.com/j/jwer.

Masoud, N. (2014). Background to the Libyan economic reform programme lessons and 
challenge. International Review of Social Sciences and Humanities 6(2).

Mir, M.Z. and Rahaman, A.S. (2005). The adoption of international accounting standards in Bangladesh: An exploration of rationale and process. Accounting, Auditing and Accountability Journal 18(6), 816-841.

Mirza, A.A., Holt, G.J. and Orrel, M. (2006). IFRS: Workbook and guide. USA: John Wiley and Son Inc.

Niskanen, J., Kinnunen, J. and Kasanen, E. (2000). The value relevance of IAS reconciliation components: Empirical evidence from Finland. Journal of Accounting and Public Policy 19, 119-137. http://dx.doi.org/10.1016/S0278-4254(00)00002-8.

Nobes, C. (1998). Towards a general model of the reasons for international differences in financial reporting. Abacus 34(2), 162-187. http://dx.doi.org/10.1111/1467-6281.00028.

Paananen, M. and Lin, H. (2009). The development of accounting quality of IAS and IFRS over time: The case of Germany. Journal of International Accounting Research 8(1), 31-55.

Papadatos, K. and Bellas, A. (2011) The value relevance of accounting information under Greek and international financial reporting standards: The influence of firm-specific characteristics. International Research Journal of Finance and Economics 76, 6-23.

Pope, P.F. and McLeay, S.J. (2011). The European IFRS experiment: Objectives, research challenges and some early evidence. Accounting and Business Research 41 (3), 233-266.

Radebaugh, L.H., Gray, S.J. and Black, E.L. (2006). International accounting and multinational enterprises. New Jersey: John Wiley and Sons.

Ramanna, K. and Sletten, E. (2010). Why do countries adopt international financial reporting standards?. Working Paper, Harvard University.

Saleh, M. (2001). Accounting information disclosure and accountability: Cases from Libya. Unpublished Ph.D. Thesis, Sheffield Hallam University, UK.

Samaha, K. and Dahawy, K. (2011). An empirical Analysis of corporate governance structures and voluntary corporate disclosure in volatile capital markets: The Egyptian experience. International Journal of Accounting, Auditing and Performance Evaluation (IJAAPE) 7, (1/2), 61-93.

Schipper, K. (2007). Required disclosures in financial reports. The Accounting Review 82 (2), 301-327.

Selway, M. (2000). Over the hump. Accountancy 125(1280), 68-69.

Shipper, K. (2005). The introduction to international accounting standards in Europe: Implications for international convergence. The European Accounting Review 14, 101-126.

Sucher, P. and Jindrichovska, I. (2004). Implementing IFRS: A case study of the Czech Republic. Accounting in Europe 1, 109-141.

Tarca, A. (2004). International convergence of accounting practices: Choosing between IAS 
and US GAAP. Journal of International Financial Management and Accounting 15, 60-91.

Terzi, S. (2011). Applications of financial reporting in the European Union and Italy. Journal of Administrative Sciences, 9(1), 273-290.

Tyrrall, D., Woodward, D. and Rakhimbekova, A. (2007). The relevance of international financial reporting standards to a developing country: Evidence from Kazakhstan. The International Journal of Accounting 42(1), 82-110. http://dx.doi.org/10.1016/j.intacc.2006.12.004.

Van Hulle, K. (2003).Von den Bilanzrichtlinien zu international accounting standards. Die Wirtschaftsprüfung 56(18), 968-981.

Van Tendeloo, B. and Vanstraelen, A. (2005). Earnings management under German GAAP and IFRS. The European Accounting Review 14, 155-180.

Vellam, I. (2004). Implementation of international accounting standards in Poland: Can true convergence be achieved in practice?. Accounting in Europe 1, 143-167.

Schrand, C. and Verrecchia, R. (2002). Disclosure choice and the cost of capital: Evidence from underpricing in initial public offerings. Wharton School Working Paper.

Wagenhofer, A. (2003). Economic consequences of internet financial reporting. Schmalenbach Business Review 55(4), 262-279.

Whittington, G. (2005). The adoption of international accounting standards in the European Union. The European Accounting Review 14, 127-153.

World Bank (2013a). Libya at a glance. Retrieved 18 December 2013, available at:< $<$ http://data.worldbank.org/country/libya $>$.

World Bank (2013b). World development indicators database. 19 April, available at:< http://siteresources.worldbank.org/DATASTATISTICS/Resources/GNIPC.pdf>.

Yapa, P.W.S. (2003). Accounting education and training in ASEAN: The Western influence and the experience of Singapore, Malaysia, Indonesia and Brunei Darussalam. Research in $\begin{array}{lllll}\text { Accounting in Emerging 267-92. } & \end{array}$ http://dx.doi.org/10.1016/S1058-1995(03)05016-3.

Zeghal, D. and Mhedhbi, K. (2006). An analysis of the factors affecting the adoption of international accounting standards by developing countries. The International Journal of Accounting 41(4), 373-386. http://dx.doi.org/10.1016/j.intacc.2006.09.009.

Zeghal, D., Chtourou, S. and Sellami, Y.M. (2011). An analysis of the effect of mandatory adoption of IAS/IFRS on earnings managements. Journal of International Accounting, Auditing and Taxation 20, 61-72. http://dx.doi.org/10.1016/j.intaccaudtax.2011.06.001. 